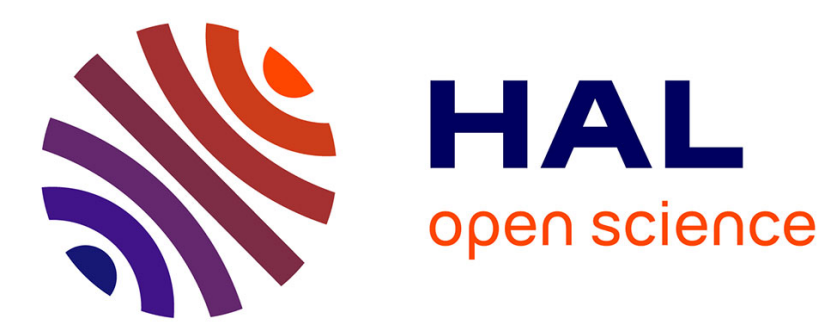

\title{
Knocking Out Multiple Genes in Cultured Primary Neurons to Study Tubulin Posttranslational Modifications
}

\author{
Satish Bodakuntla, Carsten Janke, Maria Magiera
}

\section{To cite this version:}

Satish Bodakuntla, Carsten Janke, Maria Magiera. Knocking Out Multiple Genes in Cultured Primary Neurons to Study Tubulin Posttranslational Modifications. Cytoskeleton Dynamics: Methods and Protocols, Methods in Molecular Biology, vol. 2101, pp.327-351, 2020, 10.1007/978-1-0716-02195_19. hal-03006371

\section{HAL Id: hal-03006371 https://hal.science/hal-03006371}

Submitted on 15 Nov 2020

HAL is a multi-disciplinary open access archive for the deposit and dissemination of scientific research documents, whether they are published or not. The documents may come from teaching and research institutions in France or abroad, or from public or private research centers.
L'archive ouverte pluridisciplinaire HAL, est destinée au dépôt et à la diffusion de documents scientifiques de niveau recherche, publiés ou non, émanant des établissements d'enseignement et de recherche français ou étrangers, des laboratoires publics ou privés. 
Knocking out multiple genes in cultured primary neurons to study tubulin posttranslational modifications

Satish Bodakuntla ${ }^{1,2}$, Carsten Janke ${ }^{1,2 *}$ and Maria M. Magiera ${ }^{1,2 *}$

${ }^{1}$ Institut Curie, PSL Research University, CNRS UMR3348, F-91405 Orsay, France

${ }^{2}$ Université Paris Sud, Université Paris-Saclay, CNRS UMR3348, F-91405 Orsay, France

*Corresponding authors:

Maria M. Magiera and Carsten Janke, Institut Curie, PSL Research University, CNRS

UMR3348, Centre Universitaire, Bâtiment 110, F-91405 Orsay, France

Maria.Magiera@curie.fr

Carsten.Janke@curie.fr

Running head: Knocking out multiple genes in neurons to study tubulin PTMs 


\begin{abstract}
:
Microtubules, as integral part of the eukaryotic cytoskeleton, exert numerous essential functions in cells. A mechanism to control these diverse functions are the posttranslational modifications of tubulin. Despite known for decades, relatively little insight into the cellular functions of these modifications has been gained so far. The discovery of tubulin-modifying enzymes and a growing number of available knockout mice now allows working with primary cells from those mouse models to address biological functions and molecular mechanisms behind those modifications. However, a number of those mouse models show either lethality or sterility, making it difficult to impossible to obtain a sufficient number of animals for a systematic study with primary cells. Moreover, many of those modifications are controlled by several redundant enzymes, and it is often necessary to knock out several enzymes in parallel to obtain a significant change in a given tubulin modification. Here we describe a method to generate primary cells with combinatorial knockout genotypes using conditional knockout mice. The conditional alleles are converted into knockout in the cultured primary cells by transduction with a lentivirus encoding cre-recombinase. This approach has allowed us to knock out the two main brain deglutamylases in mouse primary neurons, which leads to strongly increased polyglutamylation in these cells. Our method can be applied to measure different cellular processes, such as axonal transport, for which it can be combined with the expression of different fluorescent reporters to label intracellular proteins. Using a panel of conditional knockout mice, our method can further be applied to study the functions of a variety of tubulin modifications that require simultaneous knockout of multiple genes.
\end{abstract}

\title{
Key words:
}

Primary cells, primary hippocampal neurons, microtubules, tubulin posttranslational modifications, polyglutamylation, mouse models. 


\section{Introduction}

Microtubules, together with actin and intermediate filaments constitute the cytoskeleton of each eukaryotic cell. Microtubules assemble from evolutionarily conserved $\alpha$ - and $\beta$-tubulin heterodimers in a highly dynamic manner, and are involved in a plethora of cellular processes: they build meiotic and mitotic spindles during cell division, drive directed cell migration, determine cell shape, and serve as tracks for intracellular transport. Microtubules are particularly crucial in neurons, where they play a pivotal role in determination of neuronal polarity, dendritic arborization, axon branching and in the transport of cellular cargoes from the cell body to synaptic terminals and vice versa [1,2]. A key question is how microtubules are able to adapt their properties to participate in those highly diverse events. A mechanism to control microtubule properties that could potentially regulate these different functions are tubulin posttranslational modifications (PTMs), such as acetylation, detyrosination or polyglutamylation, which are all highly enriched in neurons [3].

Though the presence of multiple PTMs on brain tubulin was identified decades ago, their biochemical and functional characterisation became possible only after the enzymes catalysing them had been discovered (reviewed in [4]). Overexpression or knockdown of those enzymes allowed performing experiments at the cellular level thus providing first insights into the functions of tubulin PTMs (reviewed in $[5,6]$ ). In parallel, the development of a variety of mouse models lacking modifying enzymes delivered novel insights into the physiological roles of tubulin PTMs [7-15]. Approaches allowing to combine these mouse models with cell-based assays can bolster the discovery of underlying mechanisms in physiologically relevant cell types. For instance, culturing primary neurons from mouse models with altered modification levels has shed light on the role of tubulin PTMs in several neuronal functions $[11,16,7,8,17,18]$.

Culturing primary cells with altered modification levels can be straightforward for some mouse models, and very difficult for others. Mice with no sterility phenotypes can be obtained from homozygous breeding pairs, which is the case for the two enzymes involved in tubulin acetylation, $\alpha \mathrm{TAT} 1 / \mathrm{Mec}-17[19,20]$ and HDAC6 [21]. Sterile mouse strains, or mice with perinatal lethality, such as the knockout for tubulin tyrosine ligase (TTL) [11] need to be bred from heterozygous progenitors, which subsequently requires single-embryo cell cultures followed by genotyping. More difficult still are the combinatorial knockout strains, in particular with one or more of the transgenes leading to sterility. These are almost impossible to use for generating sufficient amounts of cells, as the breeding schemes are very complex, 
and the relevant offspring is statistically too rare to perform systematic cell culture studies. Here we propose a method to overcome this problem, which we have developed to study the role of tubulin polyglutamylation in neurons.

Polyglutamylation is generated by multiple enzymes belonging to the family of tubulin tyrosine ligase like proteins (TTLL) $[22,23]$ and removed by enzymes from the cytosolic carboxy peptidase (CCP) family [10,24]. Several of these enzymes are involved in controlling polyglutamylation levels in neurons: TTLL1 and TTLL7 are the major glutamylases $[8,22]$, and CCP 1 and CCP6 are the main deglutamylases [10,7]. To strongly reduce polyglutamylation in the brain, both TTLL1 and TTLL7 need to be depleted concomitantly, while to increase polyglutamylation, the inactivation of CCP1 and CCP6 is required in at least some parts of the brain, such as hippocampus [7]. In both cases, one of the two knockout mouse strains (CCP1 and TTLL1) is male sterile, and mice can thus only be bred heterozygous, which strongly reduces the probability of generating double-knockout mice. To establish a reliable and sensitive cell biological approach for studying the impact of polyglutamylation on neuronal functions, we developed a cell-culture based method to achieve increased polyglutamylation in primary hippocampal neurons, which can be easily extended to study the effects of increased or decreased PTMs other than polyglutamylation. There are two possible strategies allowing to obtain primary neurons with perturbed tubulin PTM levels: overexpressing or silencing the corresponding enzyme(s). To obtain increased polyglutamylation levels one can overexpress glutamylating enzymes, or deplete the main deglutamylating enzymes, either by RNA interference (RNAi) or by gene knockout. Overexpression of glutamylases has many drawbacks, the most important being that the amount of enzyme is far from being physiologically relevant, and could thus result in artefacts. For instance, all glutamylases overexpressed in Hela cells promiscuously glutamylated $\alpha$-and $\beta$-tubulin, while normally these enzymes are specific to either $\alpha$ - or $\beta$-tubulin [23]. Moreover, in neurons, the most relevant enzyme is the glutamylase TTLL1, which could so far not be expressed as an active enzyme in cells due to the necessity to form a complex with at least four other proteins [22]. Finally, some tubulin-modifying enzymes have been observed to bind microtubules when overexpressed (our unpublished observations), which might alter microtubule dynamics and could impair the movement of organelles on the microtubules, independently of the PTM generated by the enzyme. 
We thus strongly favour the strategy to remove the major deglutamylating enzymes, which in neurons are CCP1 and CCP6 [10,7]. We decided against RNAi, as it rarely generates a complete loss of the target transcript, which in the case of the low-expressing tubulinmodifying enzymes would be very hard to control. Thus, our method of choice was to culture primary neurons from knockout mouse strains. The breeding scheme we developed to obtain $c c p 1^{-/-} c c p 6^{-/-}$animals was very difficult for a number of reasons, such as the male infertility of $c c p 1^{-/}$mice and a general lack of fitness of the double-knockout mice (which is why we used $C c p 6^{\text {floxflox }}$ nestin-cre to breed the double-knockout animals [7]). The theoretical turnout of $1 / 16$ of this breeding scheme was not appropriate for systematic studies using primary neuronal cultures, therefore we generated a mouse model in which both, CCP1 and CCP6,

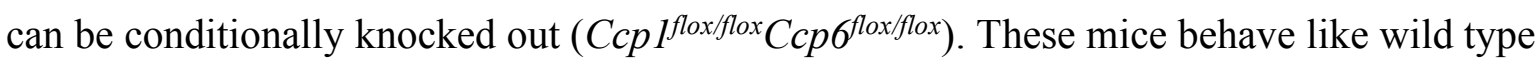
and thus can be easily bred to give homozygous embryos, which are the source of primary hippocampal neurons. Once neurons are cultured, they are transduced with a lentivirus expressing cre recombinase to convert both flox alleles into knockout alleles, leading to the removal of deglutamylases, which results in tubulin hyperglutamylation. In parallel, the neurons from the same culture are transduced with a control virus, and can be used as an internal control with normal polyglutamylation levels. To verify the effect of the cre recombinase alone, the equivalent experiment is performed using neurons from wild type embryos transduced with the same GFP- and GFP-cre viruses.

Thus, we describe a novel, physiologically relevant cell-based assay to attain excessive polyglutamylation and its possible applications. Our cell-culture based method is not limited to studying microtubules or neurons, but has broader applications in the field of cell biology. As far as microtubule PTMs are concerned, our method can be expanded to study the impact of reduced polyglutamylation (using Ttll flox/flox $T t l l 7^{f l o x}$ flox neurons) or reduced detyrosination (with $\operatorname{Vash} 1^{\text {floxfflox }}$ Vash $2^{\text {floxfflox }}$ neurons), all of which require the depletion of several genes. 


\section{Materials}

\subsection{Cloning of Cre-recombinase or Reporter Genes into Lentiviral Vector}

1. pTRIP vector with CMV promoter, pTRIP-CMV-GFP-2A (modified from Addgene \#102611)

2. Template for PCR reaction (brain cDNA or plasmid containing gene of interest)

3. KAPA HiFi HotStart $2 \times$ ReadyMix (Kapa Biosystems)

4. Specific primers

NLS-cre-FS-2A: 5' - tccactagtgtcgacATGCCCAAGAAGAAGAGGAAGGTG-3'

NLS-cre-FS-2A: 5' - catgtttttctaggtTAATCGCCATCTTCCAGCAGGC-3' (See Note 1)

5. PCR machine

6. DNase/RNase-Free Distilled Water

7. T4 DNA polymerase

8. XhoI

9. NheI

10. Buffer 2.1 (New England BioLabs)

11. $1 \times$ Tris-Borate-EDTA (TBE) buffer: add $100 \mathrm{ml}$ of $10 \times$ TBE to $900 \mathrm{ml}$ of distilled water.

12. $0.8 \%$ Agarose gel: add $4 \mathrm{~g}$ of agarose and $300 \mathrm{ml}$ of $1 \times$ TBE in a $500-\mathrm{ml}$ glass bottle. Heat the mix in the microwave oven until the agarose is dissolved and make up the volume to $500 \mathrm{ml}$ with $1 \times \mathrm{TBE}$. Add $20 \mu \mathrm{l}$ of $10 \mathrm{mg} / \mathrm{ml}$ Ethidium Bromide solution and store in incubator set at $55^{\circ} \mathrm{C}$ for not more than two weeks. Prepare the gel tray and comb of desired size, pour the agarose and let polymerize at room temperature for at least $15 \mathrm{~min}$.

13. $1 \mathrm{~kb}$ DNA Ladder

14. Gel extraction kit

15. 1.5-ml tubes

16. Chemically competent E. Coli strain Dh5alpha

17. Bacterial incubator at $37^{\circ} \mathrm{C}$.

18. LB-agar plates containing $100 \mu \mathrm{g} / \mathrm{ml}$ of Ampicillin

19. LB medium without antibiotic used for recovery of bacteria

20. LB medium with $100 \mu \mathrm{g} / \mathrm{ml}$ of ampicillin

21. 14-ml round-bottom tubes 
22. Bacterial incubator with shaking set at $37^{\circ} \mathrm{C}$.

\subsection{Lentivirus Production}

1. X-Lenti 293 T (Takara) (see Note 2).

2. Cell culture incubator at $37^{\circ} \mathrm{C}$ with $5 \% \mathrm{CO}_{2}$.

3. Tissue culture treated $75-\mathrm{cm}^{2}$ flasks.

4. Phosphate-buffered saline (PBS).

5. Trypsin.

6. Plain medium: Dulbecco`s Modified Eagle Media (DMEM) without any supplements.

7. Complete culture medium: Supplement DMEM with a final concentration of $10 \%$ FBS (vol/vol), $200 \mathrm{mM} \mathrm{L-Glutamine,} \mathrm{and} 1 \times$ Penicillin-Streptomycin. Store at $4{ }^{\circ} \mathrm{C}$.

8. Tissue culture treated 6-well plates.

9. Tissue culture treated 24-well plates.

10. Transfection reagent: TransIT-293 (Mirus Bio LLC) (see Note 3).

11. Expression and packaging plasmids: pTRIP lentiviral vector containing gene of interest under the CMV or CMV-enhanced chicken beta-actin (CAG) promoter and packaging plasmids including psPAX2 (a gift from D. Trono, Addgene plasmid \#12260) and pCMV-VSVG (a gift from B. Weinberg, Addgene plasmid \#8454). (See Note 4).

12. Virus collection medium: Neurobasal medium-PS: supplement Neurobasal medium with a final concentration of $1 \times$ Penicillin-Streptomycin. Store at $4{ }^{\circ} \mathrm{C}$. (See Note 5).

13. 15-ml and 50-ml screw-cap tubes

14. $0.45 \mu \mathrm{m}$ filters and $20-\mathrm{ml}$ syringes

15. 1.5- and 2-ml tubes

\subsection{Mouse Primary Hippocampal Neuron Cultures and Lentiviral Transduction}

1. DNase/RNase-Free Distilled Water

2. $1 \mathrm{mg} / \mathrm{ml}$ poly-D-Lysine: add $50 \mathrm{ml}$ of DNase/RNase-Free distilled water to $50 \mathrm{mg}$ of poly-D-Lysine bottle. Aliquot by $5 \mathrm{ml}$ or $10 \mathrm{ml}$ in sterile $15-\mathrm{ml}$ tubes and store at $20^{\circ} \mathrm{C}$.

3. Autoclaved distilled water

4. Tissue culture treated $75-\mathrm{cm}^{2}$ flasks

5. Dissection medium: add $10 \mathrm{ml}$ of $10 \times \mathrm{HBSS}$ and $1 \mathrm{ml}$ of $1 \mathrm{M}$ HEPES solution to $89 \mathrm{ml}$ of DNase/RNase-Free distilled water.

6. Dissection tools

7. Tissue culture-treated $100-\mathrm{mm}$ dishes 
8. Tissue culture-treated $60-\mathrm{mm}$ dishes

9. 15-ml screw-cap tubes

10. $10 \times$ Trypsin (2.5\%), no phenol red. Aliquot by $500 \mu \mathrm{l}$ in $1.5-\mathrm{ml}$ tubes and store at $20^{\circ} \mathrm{C}$. Avoid repeated freeze-thaw cycles.

11. Plating medium: add $5 \mathrm{ml}$ of filter sterilized heat inactivated horse serum, $1.3 \mathrm{ml}$ of glucose and $1 \mathrm{ml}$ of $100 \times$ Penicillin-Streptomycin to $93.7 \mathrm{ml}$ of Minimum Essential Medium. Prepare fresh before use.

12. $70-\mu \mathrm{m}$ cell strainers

13. $\mathrm{KOVA}^{\mathrm{TM}}$ Glasstic ${ }^{\mathrm{TM}}$ Slide 10 with Grids (Fisher Scientific)

14. 35-mm glass bottom dishes

15. Tissue culture treated 6-well plates

16. Tissue culture treated $24-w e l l$ plates

17. $12-\mathrm{mm}$, No.1.5H, round cover slips

18. Tissue culture treated $12-w e l l$ plates

19. B27 supplement (Thermo Fisher). Aliquot by $1 \mathrm{ml}$ in $1.5-\mathrm{ml}$ tubes and store at $-20^{\circ} \mathrm{C}$. Avoid repeated cycles of freeze-thawing.

20. Neurobasal-PS: supplement Neurobasal medium with a final concentration of $1 \mathrm{X}$ Penicillin-Streptomycin. Store at $4^{\circ} \mathrm{C}$.

21. B27 medium: add $2 \mathrm{ml}$ of $50 \times \mathrm{B} 27$ solution and $1 \mathrm{ml}$ of Glutamax ${ }^{\mathrm{TM}}$ supplement to 97 $\mathrm{ml}$ of neurobasal medium-PS. Prepare fresh for each experiment.

22. $2 \times$ B27 medium: add $2 \mathrm{ml}$ of $50 \times \mathrm{B} 27$ solution and $1 \mathrm{ml}$ of Glutamax ${ }^{\mathrm{TM}}$ to $47 \mathrm{ml}$ of neurobasal-PS medium. Prepare fresh for each experiment.

\subsection{Genotyping}

1. 2\% Agarose: add $10 \mathrm{~g}$ of agarose and $300 \mathrm{ml}$ of $1 \times \mathrm{TBE}$ in a $500-\mathrm{ml}$ glass bottle. Heat the mix in the microwave oven until the agarose is dissolved and make up the volume to $500 \mathrm{ml}$ with $1 \times \mathrm{TBE}$. Add $20 \mu \mathrm{l}$ of $10 \mathrm{mg} / \mathrm{ml}$ Ethidium Bromide solution and store in incubator set at $55^{\circ} \mathrm{C}$ for not more than two weeks. Prepare the gel tray and comb of desired size, pour the agarose and let polymerize at room temperature for at least $15 \mathrm{~min}$.

2. 100 bp DNA Ladder.

3. $10 \mathrm{mg} / \mathrm{ml}$ Proteinase $\mathrm{K}$ : Dissolve $100 \mathrm{mg}$ of proteinase $\mathrm{K}$ in $10 \mathrm{ml}$ of autoclaved distilled water. Aliquot and store at $-20^{\circ} \mathrm{C}$ indefinitely.

4. $1 \mathrm{M}$ Tris- $\mathrm{HCl} \mathrm{pH} 8$ : dissolve $12.1 \mathrm{~g}$ of Tris in $100 \mathrm{ml}$ autoclaved distilled water and adjust to $\mathrm{pH} 8$ with $\mathrm{HCl}$. Filter sterilize and store at room temperature. 
5. $5 \mathrm{M} \mathrm{NaCl}$ : dissolve $29.2 \mathrm{~g}$ of $\mathrm{NaCl}$ in $100 \mathrm{ml}$ autoclaved distilled water. Filter sterilize and store at room temperature.

6. $0.5 \mathrm{M}$ EDTA pH 8: dissolve $14.6 \mathrm{~g}$ of EDTA in $100 \mathrm{ml}$ autoclaved distilled water and adjust to $\mathrm{pH} 8$ with $\mathrm{KOH}$. Filter sterilize and store at room temperature.

7. Tail lysis buffer: $0.1 \mathrm{M}$ Tris- $\mathrm{HCl} \mathrm{pH} 8,0.2 \mathrm{M} \mathrm{NaCl}, 5 \mathrm{mM}$ EDTA and $0.4 \%$ SDS. Mix $50 \mathrm{ml}$ of $1 \mathrm{M}$ Tris- $\mathrm{HCl} \mathrm{pH} 8,20 \mathrm{ml}$ of $5 \mathrm{M} \mathrm{NaCl}, 5 \mathrm{ml}$ of $0.5 \mathrm{M}$ EDTA pH 8 and $10 \mathrm{ml}$ of $20 \%$ SDS and complete the volume to $500 \mathrm{ml}$ with distilled water.

8. Specific primers.

9. For CCP1, primer mix 1: mix primers (5'-TTAAGCAGTGGCTGCCGGAGTGC-3') and (5'-GTCTACAGCCACGTGCTCAGCAAAGG-3') at 1:1 and primer mix 2: Mix primers (5'- GGTCATCTTGTAACAGTAGGGAAATCAAGCC-3') and (5'GGAAAGCATAGCATCATGTTAAAACTCCCTCC-3') at 1:1.

10. For CCP6, primer mix 1: mix primers (5'GAATGGCAATGAGATCACCACTCTCCAGC -3') and (5'CTGTTGGGTGTCTGAGGCAAACACTTCC -3') at 1:1 and primer mix 2: Mix primers (5'- AGGTGTTCAGTGTAAAAGGAATCTGGTCCC -3') and (5'CTGTTGGGTGTCTGAGGCAAACACTTCC -3') at 1:1.

11. GoTaq ${ }^{\circledR}$ DNA polymerase (Promega), use according to manufacturer's instructions.

12. Electrophoresis cell: Mini-PROTEAN ${ }^{\circledR}$ cell with a PowerPac ${ }^{\mathrm{TM}}$ power supply (Bio$\mathrm{Rad})$.

\subsection{SDS-Polyacrylamide Gel Electrophoresis and Immunoblotting}

1. $5 \times$ Laemmli sample buffer: $400 \mathrm{mM}$ Tris-HCl pH 6.8, $450 \mathrm{mM}$ DTT, $10 \%$ (wt/vol) SDS and $50 \%$ (vol/vol) glycerol. Preheat $16 \mathrm{ml}$ of $1 \mathrm{M}$ Tris-HCl pH 6.8 to app. $40^{\circ} \mathrm{C}$, add $2.6 \mathrm{~g}$ of DTT and $4 \mathrm{~g}$ of SDS. Stir the solution gently using a magnetic stirrer and add $20 \mathrm{ml}$ of $100 \%$ glycerol. Continue stirring until the solution is homogenous and add a pinch of Bromophenol blue to reach the desired intensity of colour. Aliquot and store at $-20^{\circ} \mathrm{C}$ indefinitely.

2. Acrylamide/bis-acrylamide stock solution: $40 \%$ Acrylamide supplemented with $1.04 \%$ (wt/vol) Bis N,N'-Methylene-Bis-Acrylamide. Store at $4^{\circ} \mathrm{C}$ for up to 6 months.

3. $4 \times$ resolving gel buffer: $1.5 \mathrm{M}$ Tris- $\mathrm{HCl} \mathrm{pH} 8.8$ and $0.4 \%$ SDS. Dissolve $36.3 \mathrm{~g}$ of Tris in autoclaved distilled water and adjust to $\mathrm{pH} 8.8$ with $\mathrm{HCl}$ for a final volume of 396 $\mathrm{ml}$. Then, add $4 \mathrm{ml}$ of $20 \%$ SDS stock solution. Filter-sterilize and store at room temperature indefinitely. (See Note 6). 
4. $4 \times$ stacking gel buffer: $0.5 \mathrm{M}$ Tris- $\mathrm{HCl} \mathrm{pH} 6.8$ and $0.4 \%$ SDS. Dissolve $12.1 \mathrm{~g}$ of Tris in autoclaved distilled water and adjust to $\mathrm{pH} 6.8$ with $\mathrm{HCl}$ for a final volume of 196 $\mathrm{ml}$. Then, add $4 \mathrm{ml}$ of $20 \%$ SDS stock solution. Filter-sterilize and store at room temperature indefinitely.

5. $\mathrm{N}, \mathrm{N}, \mathrm{N}^{\prime}, \mathrm{N}^{\prime}$-Tetramethylethylenediamine (TEMED).

6. $10 \%$ Ammonium persulfate (APS): Dissolve $1 \mathrm{~g}$ of APS in $10 \mathrm{ml}$ of autoclaved distilled water. Aliquot and store at $-20^{\circ} \mathrm{C}$ indefinitely.

7. SDS-PAGE electrophoresis equipment (Bio-Rad)

8. Electrophoresis cell: Mini-PROTEAN ${ }^{\circledR}$ cell with a PowerPac ${ }^{\mathrm{TM}}$ power supply

9. Gel running buffer: $50 \mathrm{mM}$ Tris- $\mathrm{HCl}, 384 \mathrm{mM}$ glycine and $0.1 \% \mathrm{SDS}$. Dissolve $6 \mathrm{~g}$ of Tris and $28.75 \mathrm{~g}$ of glycine in autoclaved distilled water for a final volume of $995 \mathrm{ml}$. Then, add $5 \mathrm{ml}$ of $20 \%$ SDS stock solution.

10. Trans-Blot $^{\circledR}$ Turbo $^{\text {TM }}$ Mini Nitrocellulose Transfer Packs (Biorad)

11. Trans-Blot ${ }^{\circledR}$ Turbo $^{\text {TM }}$ Transfer System (Biorad)

12. Tris-buffered saline - Tween 20 (TBST) solution: $20 \mathrm{mM}$ Tris- $\mathrm{HCl} \mathrm{pH} 7.4,140 \mathrm{mM}$ $\mathrm{NaCl}$ and $0.1 \%$ Tween 20. Dissolve $2.42 \mathrm{~g}$ of Tris and $8.18 \mathrm{~g}$ of $\mathrm{NaCl}$ in autoclaved distilled water and adjust to $\mathrm{pH} 7.4$ with $\mathrm{HCl}$ for a final volume of $999 \mathrm{ml}$. Add $1 \mathrm{ml}$ of Tween 20 to the buffer and mix well. (See Note 7).

13. TBST containing 5\% (wt/vol) fat-free dry milk: Add $0.5 \mathrm{~g}$ of milk to $10 \mathrm{ml}$ TBST.

14. Antibodies: $12 \mathrm{G} 10$, anti- $\alpha$-tubulin antibody (used at $1 / 500$ (vol/vol), developed by $\mathrm{J}$. Frankel and M. Nelson, obtained from the Developmental Studies Hybridoma Bank, developed under the auspices of the NICHD, and maintained by the University of Iowa). PolyE, anti-polyglutamylated tubulin antibody (used at 1/20,000 (vol/vol); AdipoGen). Anti-GFP antibody (used at 1/5,000 (vol/vol); Acris Antibodies).

15. Clarity ${ }^{\mathrm{TM}}$ Western ECL Substrate (Biorad)

16. Western blot developer or imager 


\section{Methods}

Here, we describe a method to obtain primary neurons in which we can induce the knockout of tubulin-modifying enzymes thus obtaining strong alterations in the levels of specific tubulin PTMs. As an example, we describe the protocol to generate hyperglutamylation in primary hippocampal neurons, which can be used to study the role of polyglutamylation in several neuronal functions, such as axonal outgrowth and branching, neuronal connectivity, or axonal transport.

Briefly, we culture hippocampal neurons from $C c p 1^{f l o x f f l o x} C c p 6^{f l o x f f l o x}$ E17.5 (embryonic day 17.5) mouse embryos and transduce them either with a GFP- or GFP-2A-cre-expressing lentivirus at DIV 0 (days in vitro). The use of lentivirus-mediated gene transfer allows a nearly complete transduction of all cells in the culture dish, and appears to not exert additional stress on the neurons, as we observe no neuronal death.

Cre-recombinase was cloned into the pTRIP vector under the CMV or the CMV-enhanced chicken beta-actin (CAG) promoter using one step sequence and ligation independent cloning (SLIC) method [26]. Considering the possibility that direct GFP-tagging of Cre protein might affect its recombinase activity, we cloned Cre behind a self-cleavable $2 \mathrm{~A}$ peptide sequence [27] present in frame with the GFP protein sequence in the vector (Fig. 1a). In cells, the crerecombinase is cleaved from GFP, which we confirmed by immunoblotting (Fig. 2b). Transduction of $C c p 1^{\text {floxfflox }} C c p 6^{\text {floxfflox }}$ neurons with GFP-2A-cre resulted in 'defloxing' of both alleles of the two genes (Fig. 4a), and a concomitant increase in tubulin polyglutamylation (Fig. 4b). In parallel, wild type neurons were transduced with the same GFP- and GFP-cre viruses to confirm that the cre-recombinase alone has no effect on polyglutamylation levels (Fig. 4c).

Thus, obtained neurons can be used to determine the impact of increased polyglutamylation on different neuronal processes including neuronal differentiation and intracellular transport, by staining organelles using commercially available dyes such as Mitotracker and Lysotracker. Furthermore, this protocol combined with lentivirus-based expression of reporter genes can extend the applications of this method to study the trafficking of other vesicles such as endosomes (Rab5, Rab7 and LAMP1), BDNF vesicles (BDNF), autophagosomes (LC3), or synaptic vesicles (Synaptotagmin, Synaptophysin). Alternatively, the system can be used to study microtubule dynamics by the use of end-binding protein- EB3 fused to GFP. 


\subsection{Cloning of Cre-Recombinase and Reporter Genes into a Lentiviral Vector}

3.1.1. Cloning of Cre-recombinase into the pTRIP vector - generation of the pTRIPCMV-GFP-2A-Cre plasmid (Fig. 1).

1. Linearize the pTRIP vector by restriction digestion with XhoI (Fig. 1a). Digest $3 \mu \mathrm{g}$ of plasmid DNA for $\sim 2.5 \mathrm{~h}$ with $0.5 \mu \mathrm{l}$ of XhoI enzyme $(20 \mathrm{U} / \mu \mathrm{l})$ in a $50 \mu \mathrm{l}$ reaction. Run the whole sample on a $0.8 \%$ agarose gel until the dye front runs out. (See Note 8)

2. Purify the digested vector from the gel using the gel purification kit. Elute the vector DNA in $50 \mu 1$ of elution buffer.

3. Amplify the cre-recombinase gene using the primers containing at least $15 \mathrm{bp}$ of homology to the ends of the vector. In a PCR tube, mix $25 \mu 1$ of $2 \times$ KAPA ready mix, $0.2 \mu 1$ of each primer $(100 \mu \mathrm{M})$, PCR substrate and make up the volume to $50 \mu 1$ with DNase/RNase-Free distilled water and perform the PCR reaction. Use the following PCR conditions: an initial step of denaturation at $95^{\circ} \mathrm{C}$ for $3 \mathrm{~min} ; 15$ cycles of amplification $\left(95^{\circ} \mathrm{C}\right.$ for $30 \mathrm{sec}$, annealing of primers at $65^{\circ} \mathrm{C}$ for $30 \mathrm{sec}$, and extension at $72^{\circ} \mathrm{C}$ for $\sim 1.5 \mathrm{~min}$ ). (See Note 9 ).

4. Run the whole sample on a $0.8 \%$ agarose gel and purify the PCR product from the gel using the gel purification kit. Elute the PCR product in $40 \mu \mathrm{l}$ of elution buffer.

5. Mix $7 \mu \mathrm{l}$ of insert or elution buffer (negative control), $2 \mu 1$ of digested vector and $1 \mu \mathrm{l}$ of buffer 2.1 in to a $1.5-\mathrm{ml}$ tube, centrifuge briefly and place on ice (Fig. 1b).

6. Add $0.3 \mu \mathrm{l}$ of T4 DNA polymerase $(3 \mathrm{U} / \mu \mathrm{l})$ to each tube and mix by firmly tapping the tube (Fig. 1b).

7. Centrifuge briefly and leave the reaction mix at room temperature for $2.5 \mathrm{~min}$ to generate 5' over-hangs (Fig. 1b). (See Note 10).

8. After the incubation, immediately transfer the tubes on ice to stop the activity of T4 DNA polymerase and leave it for $\sim 5 \mathrm{~min}$ to facilitate the annealing of single-stranded over-hangs (Fig. 1b).

9. Add $100 \mu 1$ of chemically competent $E$. coli to the DNA reaction and mix by gentle tapping at the bottom of the tube.

10. Leave the E. coli with the reaction mix on ice for $30 \mathrm{~min}$, provide heat shock at $42^{\circ} \mathrm{C}$ for $45 \mathrm{~s}$, bring back the tube on ice for $10 \mathrm{~min}$. Add $1 \mathrm{ml}$ of LB medium without antibiotics and let bacteria recover at $37^{\circ} \mathrm{C}$ for at least $1 \mathrm{~h}$.

11. After the incubation, pellet the $E$. coli cells at room temperature, 1,000 RCF for $3 \mathrm{~min}$, resuspend in $\sim 100 \mu 1$ of LB medium, plate the entire cell suspension on a LB-agarampicillin plate and incubate at $37^{\circ} \mathrm{C}$ for $16 \mathrm{~h}$. 
12. Next day, inoculate 5 to 10 colonies, each in a $14-\mathrm{ml}$ round bottom tube with $\sim 5 \mathrm{ml}$ of LB medium containing ampicillin. (See Note 11).

13. Extract the plasmid DNA and test the clones by restriction digestion with appropriate enzymes. Finally, verify the positive clones by sequencing.

\subsubsection{Cloning of reporter genes into pTRIP lentivectors - generation of the pTRIP-}

\section{CMV-reporter-GFP-2A and pTRIP-CMV-reporter-GFP-2A-Cre plasmids.}

1. Linearize pTRIP-CMV-GFP-2A and pTRIP-CMV-GFP-2A-Cre lentivectors by restriction digestion with NheI (Fig. 1a). Digest $3 \mu \mathrm{g}$ of plasmid DNA for $\sim 2.5 \mathrm{~h}$ with $0.5 \mu 1$ of NheI enzyme $(20 \mathrm{U} / \mu 1)$ in a $50-\mu 1$ reaction. Gel-purify the digested vector in $50 \mu 1$ of elution buffer. (See Note 12).

2. Amplify reporter gene using the primers containing at least $15 \mathrm{bp}$ of homology to the ends of the vector. In a PCR tube, mix $25 \mu 1$ of $2 \times$ KAPA ready mix, $0.2 \mu 1$ of each primer $(100 \mu \mathrm{M})$, PCR substrate and make up the volume to $50 \mu 1$ with DNase/RNaseFree distilled water.

3. Then follow the same procedure as in section 3.1.1, from step 3 onwards. 


\subsection{Lentivirus Production and Transduction (Fig. 2a) (See Note 13)}

Grow X-lenti 293 T cells in a $75 \mathrm{~cm}^{2}$ flask to near confluence. It is critical not to let the cells become over-confluent as it will affect the efficiency of virus production. From a confluent $75-\mathrm{cm}^{2}$ flask, $\sim 10 \times 10^{6}$ cells can be obtained. Pre-warm Trypsin, PBS, and DMEM complete culture medium to $37^{\circ} \mathrm{C}$.

\subsubsection{Day -1: Seeding cells for transfection}

1. Remove the medium from the $75 \mathrm{~cm}^{2}$ flask and gently wash the cells with $5 \mathrm{ml}$ of prewarmed PBS to remove any excess medium left in the flask.

2. Add $1 \mathrm{ml}$ of Trypsin to the flask and leave in the incubator for not more than $1 \mathrm{~min}$. Collect all the trypsinized cells in culture medium.

3. Pellet down the cells by centrifugation at $150 \mathrm{RCF}$ for $2 \mathrm{~min}$.

4. Re-suspend the cells gently in $1 \mathrm{ml}$ of complete culture medium. It is important to dissociate the cells adequately, as leaving cell clumps will reduce the transfection efficiency in later steps.

5. Count and dilute the cells to $0.15 \times 10^{6}$ cells per $\mathrm{ml}$ in complete culture medium.

6. Add $3 \mathrm{ml}$ of the cell suspension $\left(0.45 \times 10^{6}\right.$ cells $)$ per well of a 6 -well plate and leave the plate in the cell culture incubator $\left(37^{\circ} \mathrm{C}, 5 \% \mathrm{CO}_{2}\right)$.

\subsubsection{Day 0: Transfection of plasmid DNA}

Pre-warm the DMEM complete culture medium and plain DMEM to $37^{\circ} \mathrm{C}$. The following protocol gives volumes for transfection of one well of a 6-well plate for each lentiviral vector, GFP and GFP-2A-Cre.

1. Mix $1.6 \mu \mathrm{g}$ of lentiviral plasmid of interest with $0.4 \mu \mathrm{g}$ of pCMV-VSVG and $1 \mu \mathrm{g}$ of psPAX2 in a $1.5-\mathrm{ml}$ tube.

2. Mix the TransIT-293 transfection reagent by gently inverting the tube. Add $8 \mu 1$ of TransIT-293 to $200 \mu 1$ of plain DMEM medium in a $1.5-\mathrm{ml}$ tube.

3. Mix the diluted TransIT-293 well by vortexing for $\sim 10 \mathrm{~s}$ and spin shortly to collect all the liquid in the bottom of the tube.

4. Add $200 \mu 1$ of the diluted TransIT-293 reagent to $3 \mu \mathrm{g}$ of plasmid DNA mix. (See Note 14).

5. Mix the tube gently by inverting and leave under the hood for 15-20 min to allow the formation of TransIT-293-DNA transfection complexes.

6. During the incubation time, replace the medium of the cells with $2 \mathrm{ml}$ of fresh, prewarmed complete culture medium. 
7. After the incubation time, gently tap the tube containing the TransIT-293-DNA transfection mix and add $200 \mu 1$ of the mix dropwise into each well.

\subsubsection{Day 1: Replace culture medium with virus collection medium}

1. After $16 \mathrm{~h}$ of transfection, aspirate the complete culture medium and gently add $3 \mathrm{ml}$ of prewarmed virus collection medium on the cells. To avoid keeping cells for too long outside the cell culture incubator, treat one plate at the time. (See Note 15).

\subsubsection{Day 2: Virus collection}

After 24-30 h after medium change, collect the medium containing the lentivirus (see Note 16).

1. Collect the medium containing the lentivirus in a $15-\mathrm{ml}$ or $50-\mathrm{ml}$ screw-cap tube.

2. Filter the medium through a $0.45 \mu \mathrm{m}$ syringe filter to remove cell debris. (See Note 17).

3. Use the virus fresh, or gently aliquot the virus-containing medium by desired volumes in $1.5-\mathrm{ml}$ tubes and store at $-80^{\circ} \mathrm{C}$.

\subsubsection{Testing the virus}

The amount of virus to add on to the neurons has to be determined by testing the lentivirus on mammalian cell lines such as U-2 OS.

1. Prepare a cell suspension of $50,000 \mathrm{cells} / \mathrm{ml}$, plate $500 \mu \mathrm{l}$ of the cell suspension per well of a $24-w e l l$ plate and leave the plate in the incubator.

2. On the next day, thaw the lentivirus from $-80^{\circ} \mathrm{C}$ directly in the hand or under the hood. (See Note 18).

3. Gently add different volumes $(50 \mu 1,100 \mu 1,200 \mu 1,500 \mu 1)$ of lentivirus, having removed the equivalent amount of media from the wells. Leave the cells with the virus in the incubator for the next $24-48 \mathrm{~h}$.

4. Based on the GFP expression, visually estimate the number of cells transduced and the intensity of GFP-fluorescence for the different volumes used. Accordingly, determine the desired amount of virus to be added to the neurons to achieve maximum transduction efficiency. Note that the same criteria of choosing the virus volume should be applied to both GFP and GFP-2A-Cre lentiviruses. (See Note 19).

\subsubsection{Testing the cleavage of Cre-recombinase and GFP}

Once the virus volume to be used is determined, test the post-translational cleavage of Crerecombinase and GFP by immunoblotting.

1. Prepare a cell suspension of 50,000 cells $/ \mathrm{ml}$, and add $2 \mathrm{ml}$ of this suspension per well of a 6-well plate and leave it in the incubator. 
2. Next day, thaw the required amount of lentivirus and transduce the cells.

3. After $48 \mathrm{~h}$ of transduction, wash the cells at least two times with fresh medium or PBS to remove any left-over lentivirus.

4. Collect cells from each well in $500 \mu 1$ of $2 \times$ Laemmli buffer and boil for $5 \mathrm{~min}$.

5. Perform an immunoblot with an anti-GFP antibody. If the GFP and Cre are cleaved, GFP band will appear at $\sim 27 \mathrm{kDa}$, else the fusion protein will migrate at $\sim 65 \mathrm{kDa}$. In case you test the construct containing another reporter gene (vesicular marker or EB3 protein), take into the account the size of this protein. 


\subsection{Mouse Primary Hippocampal Neuron Cultures and Lentiviral Transduction}

Primary mouse hippocampal neurons are cultured from embryos at 17.5 days of gestation. In our hands, a single hippocampus gives app. $0.3 \times 10^{6}$ neurons. For each experiment in which untransduced, GFP- and GFP-cre-transduced neurons will be analysed, app. $2.2 \times 10^{6}$ cells (4 embryos) will be necessary: 6 wells of a 12 -well plate (40,000 cells per well) for genotyping, 6 wells of a 6 -well plate (80,000 cells per well) for immunoblotting, 6 glass-bottom dishes (80,000 cells per well) for imaging and two 6-well plates $(80,000$ cells per well) for conditioned medium. If immunostaining analysis of the cells is also required, the necessary number of neurons should be seeded (20,000 cells per 12-mm diameter coverslip). Accordingly, coat the required number of culture plates in forehand. (See Note 20).

\subsubsection{Poly-D-Lysine coating (See Note 21).}

1. Thaw frozen aliquots of poly-D-Lysine directly in the hands.

2. Add $500 \mu 1$ of $1 \mathrm{mg} / \mathrm{ml}$ poly-D-Lysine solution to the $35-\mathrm{mm}$ glass bottom dishes ensuring it covers only the glass surface of the dish. For coating each well of a 12-well and 6-well dishes, 500 and $800 \mu 1$ of poly-D-Lysine is used, respectively. For coating glass coverslips, put them one-by-one in 24-well plate wells and add $80 \mu 1$ of poly-DLysine to cover the surface of coverslips.

3. Leave the dishes in the cell culture incubator for at least $4 \mathrm{~h}$ or overnight.

4. Remove the poly-D-Lysine and wash the dishes by adding $\sim 2 \mathrm{ml}$ of autoclaved distilled water to the dishes and plate wells. Add $1 \mathrm{ml}$ of distilled water to coverslips in 24-well plates. Repeat the wash three times.

5. Finally, remove any remaining droplets of water by using the vacuum pump.

6. Leave the dishes open under the cell culture hood until they are completely dry. Use the poly-D-Lysine-coated dishes immediately or store at $4^{\circ} \mathrm{C}$, sealed with parafilm until further use.

\subsubsection{Neuronal cell culture}

Before proceeding, prepare freshly anticipated amounts of dissection medium, plating medium, $1 \times$ B27 medium and $2 \times$ B27 medium in tissue culture flasks. Keep the plating medium and B27 medium in the cell culture incubator for $2 \mathrm{~h}$ to allow it to equilibrate its temperature and $\mathrm{CO}_{2}$ content. Thaw adequate amount of $10 \times$ trypsin aliquots and filtersterilized horse serum. For up to 5 embryos, we typically prepare $100 \mathrm{ml}$ of both dissection and plating media, $30 \mathrm{ml}$ of $1 \times \mathrm{B} 27$ media, $20 \mathrm{ml}$ of $2 \times \mathrm{B} 27$ medium, $500 \mu 1$ of trypsin and $5 \mathrm{ml}$ of horse serum. 
1. Sacrifice a 17.5-days-pregnant dam by cervical dislocation and collect the embryos in a 100-mm dish containing $\sim 5 \mathrm{ml}$ of dissection medium.

2. Rapidly decapitate the embryos, dissect the brains and separate the two hemispheres (Fig. 3a). Collect all the hemispheres in a $60-\mathrm{mm}$ dish containing $\sim 3 \mathrm{ml}$ of dissection medium.

3. With the help of a stereo microscope, carefully remove the meninges off the hemisphere and dissect out the hippocampus (Fig. 3a). Collect the hippocampi in a 15$\mathrm{ml}$ tube containing $4.5 \mathrm{ml}$ of dissection medium. (See Note 22).

4. Add $0.5 \mathrm{ml}$ of $2.5 \%$ trypsin $(10 \times)$ to the tube containing hippocampi, mix gently and place it in the incubator or water bath at $37^{\circ} \mathrm{C}$ for $20-25 \mathrm{~min}$. During the incubation time, gently mix the tube regularly by inverting.

5. Meanwhile, fire-polish the edges of two glass Pasteur-pipettes using Bunsen burner to make their sizes successively smaller (Fig. 3b). Label the treated pipettes according to their size and fix sterile rubber bulbs at their ends.

6. Coat the inner walls of the glass pipettes with horse serum by pipetting it up and down several times, to avoid the sticking of cells to the pipette walls while triturating.

7. After the trypsinization, use the largest triturating pipette to carefully remove the trypsin from the 15-ml tubes. (See Note 23).

8. Wash off the excess trypsin from the tissue by incubating with $\sim 5 \mathrm{ml}$ of plating medium for $5 \mathrm{~min}$. Repeat the wash once more and resuspend the hippocampi in $\sim 1 \mathrm{ml}$ of plating medium.

9. Gently aspirate and expulse hippocampi 6 to 10 times using the largest triturating pipette, avoiding formation of air bubbles. Repeat the procedure using the smaller pipette. (See Note 24).

10. Pass the cell suspension through a $70-\mu \mathrm{m}$ cell strainer to remove any tissue clumps. (See Note 25).

11. Count cells and prepare a cell suspension at 40,000 cells $/ \mathrm{ml}$. Add $500 \mu \mathrm{l}$ of the cell suspension on each glass coverslip (for immunostaining), $1 \mathrm{ml}$ in each 12 -well plate well (for genotyping), $2 \mathrm{ml}$ in each 6-well plate well (for immunoblotting and for conditioned medium) and in each 35-mm glass bottom dish (for live-cell imaging). The day of seeding is considered as DIV 0 (days in vitro 0 ). (See Note 26).

12. Two to three hours after plating, change the medium for the Neurbasal-B27. For the neurons for conditioned medium, simply replace the plating medium by $1 \times$ B27 medium. For neurons to be transduced with the lentiviral particles, see next chapter. 


\subsubsection{Transduction of neurons}

In this protocol we assume that the volume of the virus added to the neurons constitutes $50 \%$ of the total volume of the culture medium. As the virus-containing-medium (Neurobasal) does not contain the supplements necessary for neurons to grow, it is essential to add twice the final amount of these supplements to the medium $(2 \times$ B27 medium $)$ used to complement the virus-containing medium volume.

1. Prepare fresh (see chapter 3.2), or thaw the required amount of the desired lentiviruses (for example GFP- and GFP-2A-Cre encoding lentiviruses) under the hood.

2. In the meantime, remove the plating medium and add 0.5 volume of $2 \times$ B27 medium to the neurons. For example, for a 35-mm glass-bottom dish add $1 \mathrm{ml}$ of $2 \times$ B27 medium.

3. Once the virus is completely thawed, add 0.5 volume of the lentivirus-containing medium (for a 35-mm glass bottom dish, add $1 \mathrm{ml}$ of lentivirus). For untransduced samples, add Neurobasal-PS medium. Rapidly return the cells to the cell culture incubator.

\subsection{Genotyping}

Prior to the analysis of the transduced neurons, confirm the genotype of neurons in order to verify the activity of the cre-recombinase.

1. Add $100 \mu \mathrm{l}$ of the lysis buffer containing proteinase $\mathrm{K}$ to each well of 12 -well dish and lyse the neurons using a p200 micropipette.

2. Incubate the lysate at $55^{\circ} \mathrm{C}$ for at least $4 \mathrm{~h}$ or overnight.

3. Boil the samples at $95^{\circ} \mathrm{C}$ for $10 \mathrm{~min}$.

4. In order to determine the genotype of $\mathrm{CCP} 1$ and $\mathrm{CCP} 6$, perform PCR reactions using primer mix 1 and primer mix 2 for both genes.

5. Set up separate PCR reactions for each primer mix $(25 \mu \mathrm{l})$ : Add $18 \mu \mathrm{l}$ of water, $5 \mu 1$ of $5 \times$ buffer, $0.5 \mu \mathrm{l}$ of $10 \mathrm{mM}$ dNTPs, $0.5 \mu 1$ of GoTaq ${ }^{\circledR}$ DNA polymerase $(1 \mathrm{U} / \mu \mathrm{l})$, $0.1 \mu 1$ of primer mix and $1 \mu 1$ of DNA sample.

Use the following PCR conditions: an initial step of denaturation at $96^{\circ} \mathrm{C}$ for $5 \mathrm{~min} ; 35$ cycles of amplification $\left(96^{\circ} \mathrm{C}\right.$ for $30 \mathrm{sec}$, annealing of primers at $63.5^{\circ} \mathrm{C}$ for $30 \mathrm{sec}$, and extension at $72^{\circ} \mathrm{C}$ for $\sim 30 \mathrm{sec}$ ).

6. Run $10 \mu 1$ of the PCR product on the $2 \%$ agarose gel. (See Note 27).

7. For CCP1, primer mix 1 amplifies $\sim 400 \mathrm{bp}$ fragment in the flox allele (and no product in the knockout allele) and the primer mix 2, 600 bp fragment in the knockout allele (and no product in the flox allele). For CCP6, primer mix 1 amplifies $\sim 40 \mathrm{bp}$ 
fragment in the flox allele (and no product in the knockout allele) and the primer mix 2, $\sim 800$ bp fragment in the knockout allele (and no product in the flox allele) (Fig. 4a). Note, that the primer mix 1 still amplifies a faint band in both CCP1 and CCP6, suggesting a residual presence of flox alleles, which could come from untransduced cells.

\subsection{SDS-polyacrylamide gel electrophoresis and immunoblotting}

Prior to the analysis of the transduced neurons, collect the samples to later verify the effect of the depletion of CCP1 and CCP6 on the levels of tubulin polyglutamylation in transduced neurons by immunoblot (Fig. 4b).

1. Add $200 \mu 1$ of the Laemmli sample buffer to each well of 6-well dish and lyse the neurons using a p200 micropipette. (See Note 28).

2. Boil the samples at $95^{\circ} \mathrm{C}$ for $5 \mathrm{~min}$ and spin down briefly.

3. Set up the gel casting apparatus according to manufacturer's description. For one 1-mm-thick $10 \%$ acrylamide gel, mix $1.25 \mathrm{ml}$ of acrylamide/bis solution, $1.25 \mathrm{ml}$ of $4 \times$ resolving buffer and $2.5 \mathrm{ml}$ of distilled water in a $15-\mathrm{ml}$ tube. Add $40 \mu \mathrm{l}$ of $10 \%$ APS and $5 \mu 1$ of TEMED, mix gently by inverting the tube and immediately pipette the solution into the preassembled casting apparatus. Add a small layer of distilled water $(\sim 300 \mu 1)$ on the gel solution and leave it undisturbed for at least 30 min.

4. Remove the overlaid water layer by inverting the gel and drain off the remaining water droplets with a tissue paper.

5. Prepare the stacking gel: for one $1 \mathrm{~mm}$-thick resolving gel, mix $175 \mu 1$ of acrylamide/bis solution, $406 \mu 1$ of $4 \times$ stacking buffer and $1044 \mu 1$ of distilled water. Add $10 \mu 1$ of $10 \%$ APS and $4 \mu 1$ of TEMED, mix gently by inverting the tube and immediately pipette the solution onto the polymerized resolving gel. Carefully insert a comb into the stacking gel and allow it to polymerize for $30 \mathrm{~min}$.

6. Assemble the electrophoresis tank and fill the chamber with the gel running buffer. Remove the comb and wash the wells with the buffer.

7. Boil the samples at $95^{\circ} \mathrm{C}$ for 5 min, spin down briefly, load the samples on the gel and separate the proteins at $200 \mathrm{~V}$ until the dye front runs out from the gel. (See Note 29).

8. Transfer the separated proteins from the gel to a nitrocellulose membrane using the Biorad Trans-Blot ${ }^{\circledR}$ Turbo system, according to manufacturer's instructions.

9. Block the membrane in TBST containing 5\% skimmed milk for $1 \mathrm{~h}$, with gentle shaking, at room temperature. 
10. Incubate the membrane with primary antibodies (12G10, PolyE or anti- GFP) diluted in TBST containing $2.5 \%$ skimmed milk for $1 \mathrm{~h}$, with gentle shaking, at room temperature.

11. Wash the membrane $3 \times 5 \mathrm{~min}$ in TBST with vigorous shaking.

12. Incubate the membrane with secondary, HRP-conjugated antibodies (anti-mouse for 12G10; anti-rabbit for poly E and anti-GFP) diluted in TBST buffer for $1 \mathrm{~h}$, with gentle shaking, at room temperature.

13. Wash the membrane $3 \times 5 \mathrm{~min}$ in TBST with vigorous shaking.

14. Reveal the chemiluminescence signal on the membrane by incubating it with the ECL solution according to manufacturer's instructions and using the available equipment (either chemical or digital imager) 


\section{4. $\quad$ Notes}

1. The primer sequence written in lower case shares homology with the ends of the target vector, pTRIP-CMV-GFP-2A

2. Always use cells which have been in culture for no more than 5-8 passages, as using cells after multiple passages may reduce the viral titre. It is very important to ensure that $\mathrm{X}$ lenti $293 \mathrm{~T}$ cells are mycoplasma free, as mycoplasma contamination can affect the virus production efficiency.

3. We have used other transfection reagents such as jetPEI for virus production and found that the virus titre produced is lower than when using TransIT-293.

4. We used pTRIP vector with CAG and CMV promoters for the experiments. In our experience, there is no difference in their expression levels in neurons at young age. However, if transduction to be performed at a differentiated stage, we suggest to use vectors with CAG promoter, as it expressed better than CMV promoter in mature neurons.

5. The choice of medium used for virus-production depends on the medium preferred by the cells you intend to transduce. In this case, we used Neurobasal medium as our target cells were neurons.

6. If there is a need to separate alpha-and beta-tubulins on the SDS-PAGE, we recommend using a different gel composition [25].

7. As Tween 20 is highly viscous, add it to the TBS solution using a cut p1000 pipette tip and rinsing the tip by repeated pipetting

8. It is crucial to run the gel for a sufficiently long time, as it will aid in separating the cut from the uncut vector, reducing the contamination with uncut vector during purification of digested vector.

9. Extension time needs to be adjusted based on the length of the amplicon and speed of the polymerase. In our case, we consider that polymerase requires $\sim 1$ min to amplify $\sim 1 \mathrm{~kb}$ of DNA template

10. The timing of the reaction mix is to be strictly followed. Leaving the reaction mix for less or more time will reduce the efficiency of SLIC.

11. Usually, when the SLIC reaction is efficient, we get $\sim 80$ colonies in the positive plate and $\sim 5$ colonies in negative control plate. If the SLIC efficiency is poor, you will get less colonies in the positive plate. If the vector is not properly digested, you will get many colonies in the negative control plate. 
12. NheI is selected when the reporter gene is to be C-terminally GFP-tagged. Use BsrGI enzyme when the reporter gene is to be N-terminally GFP-tagged.

13. Rules and regulations regarding working with lentiviral particles are specific to each country. Please enquire about and follow the rules that apply in your country.

14. Always add the diluted TransIT-293 into DNA mix, and not the other way around.

15. Usually we add $3 \mathrm{ml}$ of virus collection medium per well of a 6-well plate. It is possible to obtain a more concentrated virus by adding a lower volume of medium. The minimal volume possible is $1.5 \mathrm{ml}$.

16. Avoid exceeding this time, as it might reduce the competence of produced lentivirus.

17. Do not use $0.2 \mu \mathrm{m}$ filter, as it might damage the lentivirus.

18. As viruses are very sensitive to mechanical stress, do not accelerate thawing by pipetting or shaking.

19. As a general rule, transduction of primary cell cultures is difficult compared to cell lines. Therefore, the intensity of GFP-fluorescence in U-2 OS cells and neurons might be different. If the GFP intensities are very different, then we suggest to use wild type neurons for testing and determining the amount of virus to be added.

20. For cleaning coverslips, place a maximum of 200 coverslips in a $100-\mathrm{ml}$ glass bottle. Wash them by shaking for at least $30 \mathrm{~min}$ in $3 \mathrm{M} \mathrm{HCl}, 2 \times 10 \mathrm{~min}$ in distilled water, $3 \times 10 \mathrm{~min}$ in $95 \% \mathrm{EtOH}$ and $2 \times 10 \mathrm{~min}$ in distilled water. Let the coverslips dry under the hood or in an oven.

21. Proper coating of the surface with poly-D-Lysine is crucial for attachment and development of the neurons. If the dishes are not coated properly, it will cause the neurons to clump or not adhere well.

22. Success of primary neuron culture depends on the time of dissection (from sacrificing the dam to collecting all the hippocampi) and should take no longer than $90 \mathrm{~min}$.

23. Be careful as the hippocampi tend to be aspirated by the suction created by pipetting. If it is difficult to remove the trypsin without the hippocampi, proceed immediately to washes. The tendency of hippocampi to be aspirated with the pipette suction reduces after washes with plating medium.

24. Do not exceed the number of trituration passages through the Pasteur pipettes, even if pieces of tissue are still visible at the end of the procedure.

25. Some labs use $40 \mu \mathrm{m}$ cell strainers to pass the cell suspension. In our hands, $70-\mu \mathrm{m}$ cell strainers worked best without affecting the survival of neurons. 
26. For live-cell imaging and immunostaining, it is important to plate neurons at a lowdensity. Neurons seeded at high-density will have overlapping axons and dendrites, making it difficult to use them for analysis.

27. Usually, $10 \mu \mathrm{l}$ of PCR product is sufficient to visualize the amplification. If there is an unexpected problem with the gel, make a fresh gel and run another $10 \mu 1$ from the remaining PCR product.

28. Depending on the day of the experiment, the sample might need to be further diluted before immunoblotting in order to not overload the gel with protein.

29. When analysing the differences in levels of tubulin modifications, we strongly recommend to load low amounts of protein on the gel [25]. 
Fig. 1. Strategy used to clone the cre-recombinase and reporter genes into the pTRIP lentiviral vector. (a) Vector map of the pTRIP-CMV-EGFP-2A lentiviral plasmid. To allow the cleavage of cre recombinase and GFP, cre was inserted into the XhoI site. For further insertion of additional reporter genes, the backbone can be opened with NheI to generate a Cterminally GFP-tagged fusion protein, or with BsrGI to generate a N-terminally GFP-tagged fusion protein. (b) Flowchart of the sequence- and ligation-independent cloning (SLIC) method (adapted from [26]).

Fig. 2. Production and functional analysis of the lentiviral particles. (a) Flowchart of the production of lentiviral particles. X-lenti $293 \mathrm{~T}$ cells are transfected with the envelope vector (pCMV-VSV-G), packaging vector (psPAX2) and the backbone pTRIP vector containing the gene of interest. On the day following the transfection, the medium is replaced by the desired virus-collection medium, which is collected $24-36 \mathrm{~h}$ later, filtered and aliquoted. The medium can either be directly used to transduce cells, or frozen for later use. Note that the medium changes colour to more orange during virus production. (b) Immunoblots showing the efficiency of the cleavage of the P2A site between the GFP and the cre recombinase. Extracts from U-2OS cells transduced with lentivirus encoding either GFP, or GFP-2A-crerecombinase are immunoblotted with anti-GFP antibody. In both cases, only a single band of $\sim 28 \mathrm{kDa}$, corresponding to GFP, is detected. The absence of a higher-molecular-weight band, corresponding to the fusion protein GFP-cre-recombinase, demonstrates that all GFP-cre fusion protein was cut. Total $\alpha$-tubulin (detected by the $12 \mathrm{G} 10$ antibody) is used as a loading control.

\section{Fig. 3. Mouse primary hippocampal neuron culture and the experimental design.}

(a) Representative pictures of successive steps of hippocampus dissection from an E17.5 embryonic brain. Scale bar: $2 \mathrm{~mm}$. (b) Representative images of unpolished, fire-polished and reduced-diameter Pasteur pipettes used to dissociate hippocampi. Scale bar: $2 \mathrm{~mm}$. (c) Schematic representation of the culture dishes needed for one experiment including nontransduced, GFP- and GFP-2A-cre-transduced neurons.

Fig. 4. Analysis of efficiency of the cre-mediated recombination in primary hippocampal neurons. (a) An agarose gel showing the genotypes of $C c p 1^{\text {floxfllox }} C \operatorname{cp} 6^{\text {flox } f l o x}$ neurons transduced with GFP- and GFP-2A-cre viruses. Note that in the presence of GFP alone, only flox alleles are detected, while with GFP and cre recombinase the major band comes from the 
$\mathrm{KO}$ alleles. Note the presence of a faint band (corresponding to the flox alleles) in the presence of the cre recombinase, which could come from the incomplete transduction of neuronal population. (b) Immunoblot from $C c p 1^{\text {flox fllox }} C \operatorname{cp} 6^{\text {flox/flox }}$ neurons after transduction with GFP- or GFP-2A-cre viruses. In the cells transduced with GFP-2A-cre virus, knockout of $C c p 1$ and Ccp6 result in a strong increase of tubulin polyglutamylation levels (polyE antibody). Equal loading is verified using the total $\alpha$-tubulin antibody (12G10). (c) Immunoblot showing that the cre-recombinase expressed in wild-type neurons has no effect on tubulin polyglutamylation levels (polyE antibody). Equal loading is verified using the total $\alpha$-tubulin antibody (12G10). 


\section{Acknowledgments}

This work was supported by the ANR-10-IDEX-0001-02, the LabEx CelTisPhyBio ANR-11LBX-0038. CJ is supported by the Institut Curie, the French National Research Agency (ANR) awards ANR-12-BSV2-0007 and ANR-17-CE13-0021, the Institut National du Cancer (INCA) grant 2014-PL BIO-11-ICR-1, and the Fondation pour la Recherche Medicale (FRM) grant DEQ20170336756. MMM is supported by the EMBO short-term fellowship ASTF 148-2015 and by the Fondation Vaincre Alzheimer grant FR-16055p, and SB by the FRM grant FDT201805005465. We thank C. Alberti, E. Belloir, F. Bertrand, V. DanglesMarie, I. Grandjean, C. Caspersen, H. Hermange, A. Thadal, G. Buhagiar, C. Serieyssol, S. Gadadhar, M. Sittewelle, (Institut Curie) for technical assistance. We are grateful to M.-N. Soler, C. Lovo and L. Besse from the PICT-IBiSA@Orsay Imaging Facility of the Institut Curie supported by the ANR through the "Investment for the future" program (FranceBioImaging, ANR-10-INSB-04), and to N. Manel (Institut Curie, Paris) for material and advice for the lentivirus production. We would like to thank F. Del Bene, V. Marthiens (Institut Curie) and C. González-Billault (University of Chile, Santiago, Chile) for instructive discussions and advice.

\section{References}

1. Mandell JW, Banker GA (1995) The microtubule cytoskeleton and the development of neuronal polarity. Neurobiol Aging 16 (3):229-237; discussion 238

2. Brady ST, Morfini GA (2017) Regulation of motor proteins, axonal transport deficits and adult-onset neurodegenerative diseases. Neurobiol Dis 105:273-282. doi:S09699961(17)30084-0 [pii]10.1016/j.nbd.2017.04.010

3. Janke C (2014) The tubulin code: Molecular components, readout mechanisms, and functions. J Cell Biol 206 (4):461-472. doi:jcb.201406055 [pii]10.1083/jcb.201406055

4. Janke C, Bulinski JC (2011) Post-translational regulation of the microtubule cytoskeleton: mechanisms and functions. Nat Rev Mol Cell Biol 12 (12):773-786. doi:nrm3227 [pii]10.1038/nrm3227

5. Magiera MM, Singh P, Janke C (2018) SnapShot: Functions of Tubulin Posttranslational Modifications. Cell 173 (6):1552-1552 e1551. doi:S0092-8674(18)30644-5 [pii]10.1016/j.cell.2018.05.032

6. Gadadhar S, Bodakuntla S, Natarajan K, Janke C (2017) The tubulin code at a glance. J Cell Sci 130 (8):1347-1353. doi:jcs.199471 [pii]10.1242/jcs.199471

7. Magiera MM, Bodakuntla S, Ziak J, Lacomme S, Marques Sousa P, Leboucher S, Hausrat TJ, Bosc C, Andrieux A, Kneussel M, Landry M, Calas A, Balastik M, Janke C (2018) Excessive tubulin polyglutamylation causes neurodegeneration and perturbs neuronal transport. EMBO J 37 (23):e100440. doi:embj.2018100440 [pii]10.15252/embj.2018100440 
8. Ikegami K, Mukai M, Tsuchida J-i, Heier RL, Macgregor GR, Setou M (2006) TTLL7 is a mammalian beta-tubulin polyglutamylase required for growth of MAP2-positive neurites. J Biol Chem 281 (41):30707-30716

9. Kalebic N, Sorrentino S, Perlas E, Bolasco G, Martinez C, Heppenstall PA (2013) alphaTAT1 is the major alpha-tubulin acetyltransferase in mice. Nat Commun 4:1962. doi:10.1038/ncomms2962

10. Rogowski K, van Dijk J, Magiera MM, Bosc C, Deloulme J-C, Bosson A, Peris L, Gold ND, Lacroix B, Bosch Grau M, Bec N, Larroque C, Desagher S, Holzer M, Andrieux A, Moutin M-J, Janke C (2010) A family of protein-deglutamylating enzymes associated with neurodegeneration. Cell 143 (4):564-578. doi:S0092-8674(10)01184-0 [pii]10.1016/j.cell.2010.10.014

11. Erck C, Peris L, Andrieux A, Meissirel C, Gruber AD, Vernet M, Schweitzer A, Saoudi Y, Pointu H, Bosc C, Salin PA, Job D, Wehland J (2005) A vital role of tubulin-tyrosineligase for neuronal organization. Proc Natl Acad Sci U S A 102 (22):7853-7858

12. Rocha C, Papon L, Cacheux W, Marques Sousa P, Lascano V, Tort O, Giordano T, Vacher S, Lemmers B, Mariani P, Meseure D, Medema JP, Bièche I, Hahne M, Janke C (2014) Tubulin glycylases are required for primary cilia, control of cell proliferation and tumor development in colon. EMBO J 33 (19):2247-2260. doi:10.15252/embj. 201488466

13. Bosch Grau M, Masson C, Gadadhar S, Rocha C, Tort O, Marques Sousa P, Vacher S, Bieche I, Janke C (2017) Alterations in the balance of tubulin glycylation and glutamylation in photoreceptors leads to retinal degeneration. J Cell Sci 130:938-949. doi:jcs.199091 [pii]10.1242/jcs.199091

14. Gadadhar S, Dadi H, Bodakuntla S, Schnitzler A, Bieche I, Rusconi F, Janke C (2017) Tubulin glycylation controls primary cilia length. J Cell Biol 216 (9):2701-2713. doi:jcb.201612050 [pii]10.1083/jcb.201612050

15. Giordano T, Gadadhar S, Bodakuntla S, Straub J, Leboucher S, Martinez G, Chemlali W, Bosc C, Andrieux A, Bieche I, Arnoult C, Geimer S, Janke C (2019) Loss of the deglutamylase CCP5 perturbs multiple steps of spermatogenesis and leads to male infertility. J Cell Sci 132 (3):10.1242/jcs.226951. doi:jcs.226951 [pii]10.1242/jcs.226951

16. Silva CG, Peyre E, Adhikari MH, Tielens S, Tanco S, Van Damme P, Magno L, Krusy N, Agirman G, Magiera MM, Kessaris N, Malgrange B, Andrieux A, Janke C, Nguyen L (2018) Cell-Intrinsic Control of Interneuron Migration Drives Cortical Morphogenesis. Cell 172 (5):1063-1078. doi:10.1016/j.cell.2018.01.031

17. Gilmore-Hall S, Kuo J, Ward JM, Zahra R, Morrison RS, Perkins G, La Spada AR (2019) CCP1 promotes mitochondrial fusion and motility to prevent Purkinje cell neuron loss in pcd mice. J Cell Biol 218 (1):206-219. doi:jcb.201709028 [pii]10.1083/jcb.201709028

18. Marcos S, Moreau J, Backer S, Job D, Andrieux A, Bloch-Gallego E (2009) Tubulin tyrosination is required for the proper organization and pathfinding of the growth cone. PLoS ONE 4 (4):e5405

19. Akella JS, Wloga D, Kim J, Starostina NG, Lyons-Abbott S, Morrissette NS, Dougan ST, Kipreos ET, Gaertig J (2010) MEC-17 is an alpha-tubulin acetyltransferase. Nature 467 (7312):218-222. doi:nature09324 [pii]10.1038/nature09324

20. Shida T, Cueva JG, Xu Z, Goodman MB, Nachury MV (2010) The major alpha-tubulin K40 acetyltransferase alphaTAT1 promotes rapid ciliogenesis and efficient 
mechanosensation. Proc Natl Acad Sci U S A 107 (50):21517-21522. doi:1013728107 [pii]10.1073/pnas.1013728107

21. Hubbert C, Guardiola A, Shao R, Kawaguchi Y, Ito A, Nixon A, Yoshida M, Wang X-F, Yao T-P (2002) HDAC6 is a microtubule-associated deacetylase. Nature 417 (6887):455458

22. Janke C, Rogowski K, Wloga D, Regnard C, Kajava AV, Strub J-M, Temurak N, van Dijk J, Boucher D, van Dorsselaer A, Suryavanshi S, Gaertig J, Eddé B (2005) Tubulin polyglutamylase enzymes are members of the TTL domain protein family. Science 308 (5729):1758-1762. doi:1113010 [pii]10.1126/science.1113010

23. van Dijk J, Rogowski K, Miro J, Lacroix B, Eddé B, Janke C (2007) A targeted multienzyme mechanism for selective microtubule polyglutamylation. Mol Cell 26 (3):437-448. doi:S1097-2765(07)00248-1 [pii]10.1016/j.molcel.2007.04.012

24. Tort O, Tanco S, Rocha C, Bieche I, Seixas C, Bosc C, Andrieux A, Moutin M-J, Xavier Aviles F, Lorenzo J, Janke C (2014) The cytosolic carboxypeptidases CCP2 and CCP3 catalyze posttranslational removal of acidic amino acids. Mol Biol Cell 25 (19):30173027. doi:mbc.E14-06-1072 [pii]10.1091/mbc.E14-06-1072

25. Magiera MM, Janke C (2013) Investigating tubulin posttranslational modifications with specific antibodies. In: Correia JJ, Wilson L (eds) Methods Cell Biol, vol 115.

Microtubules, in vitro, 2013/08/27 edn. Academic Press, Burlington, pp 247-267. doi:10.1016/B978-0-12-407757-7.00016-5

26. Jeong J-Y, Yim H-S, Ryu J-Y, Lee HS, Lee J-H, Seen D-S, Kang SG (2012) One-step sequence- and ligation-independent cloning as a rapid and versatile cloning method for functional genomics studies. Appl Environ Microbiol 78 (15):5440-5443. doi:AEM.00844-12 [pii]10.1128/AEM.00844-12

27. Kim JH, Lee S-R, Li L-H, Park H-J, Park J-H, Lee KY, Kim M-K, Shin BA, Choi S-Y (2011) High cleavage efficiency of a 2A peptide derived from porcine teschovirus-1 in human cell lines, zebrafish and mice. PLoS One 6 (4):e18556.

doi:10.1371/journal.pone.0018556PONE-D-11-01024 [pii] 
a

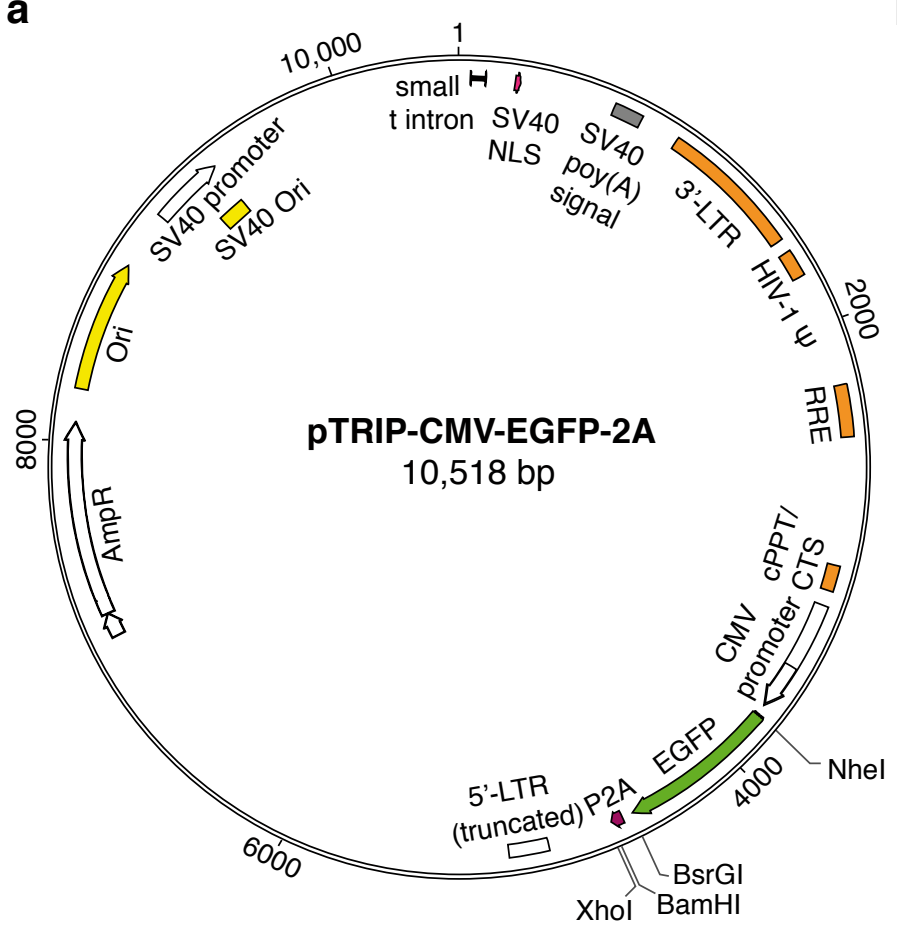

b Linearize lentiviral vector with restriction enzyme(s)

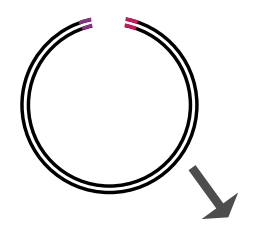

Mix 2 vol linearized vector, 7 vol insert, 1 vol buffer

Treat with T4 DNA polymerase to generate 3'-overhangs

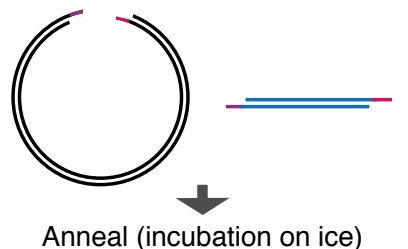

Anneal (incubation on ice)

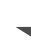

Transform into bacteria

DA repair

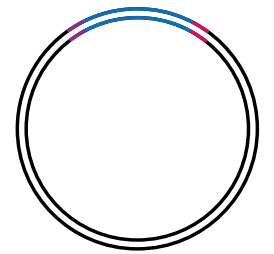


a

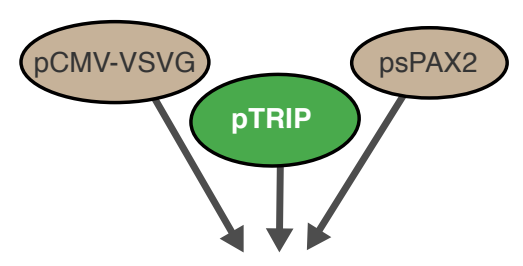

\section{Day 0}

Transfect DNA mix into X-lenti 293T cells

\section{Day 1}

Change medium for virus-collection medium

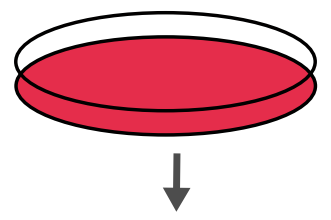

Day 2

Collect and filter the virus-containing medium
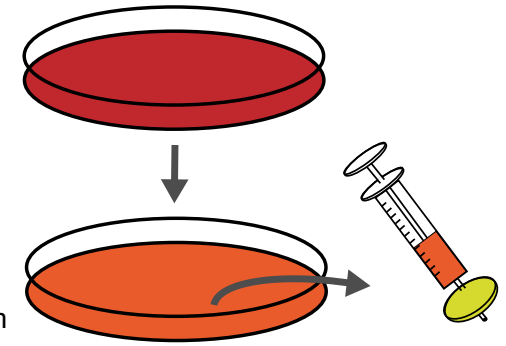

Prepare aliquots to store at $-80^{\circ} \mathrm{C}$

\section{Any day}

Thaw and add lentivirus to target cells b

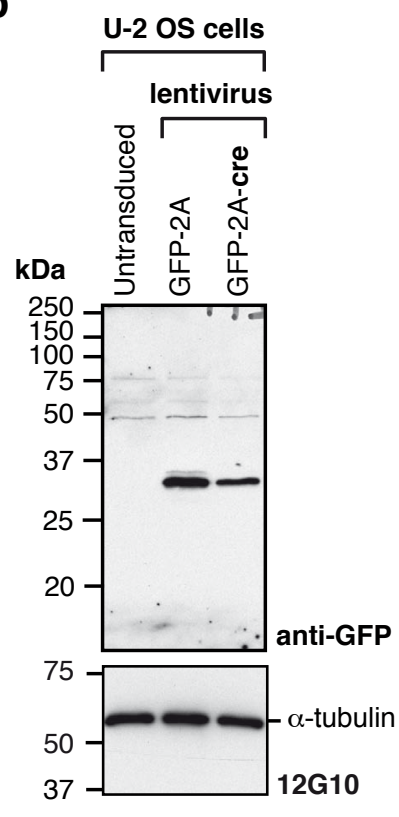


Bodakuntla et al., Figure 3

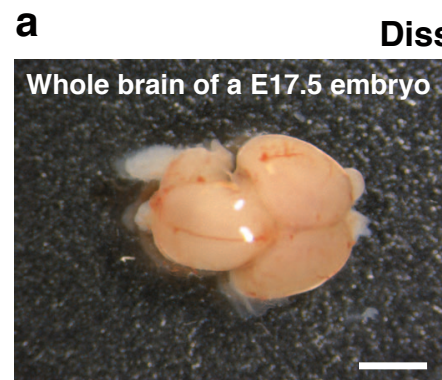

Dissection of E17.5 mouse hippocampi
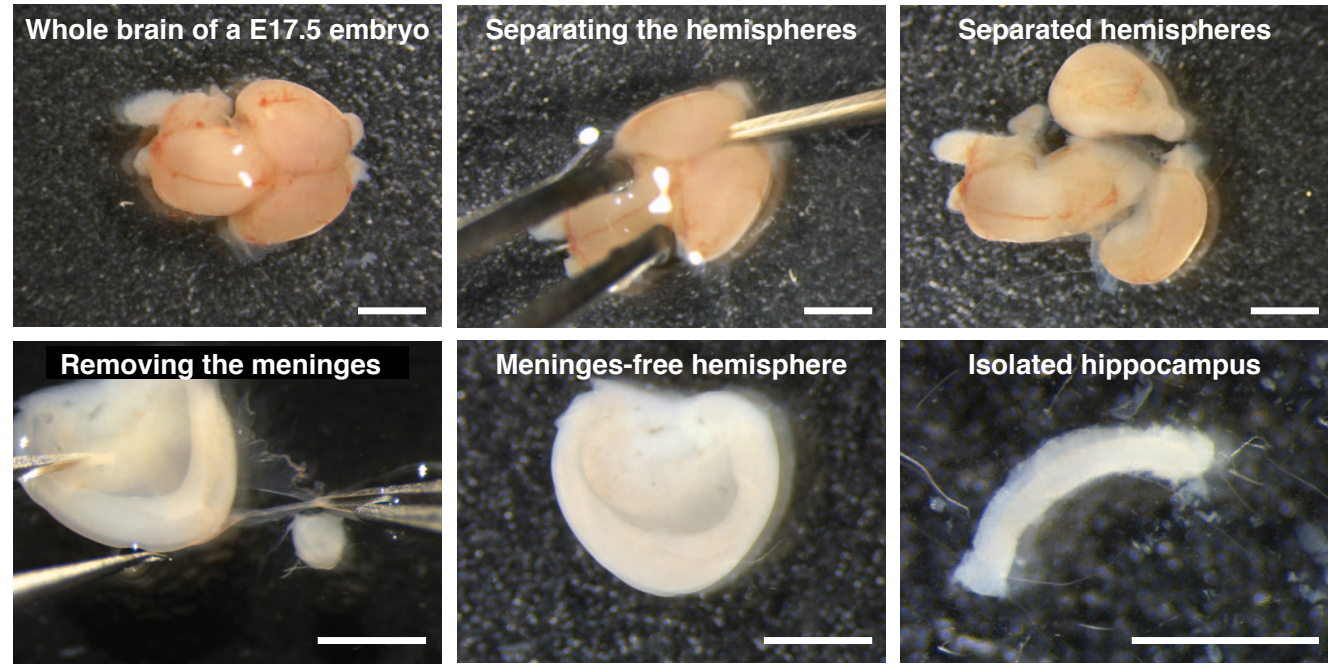

b Triturating glass pipettes

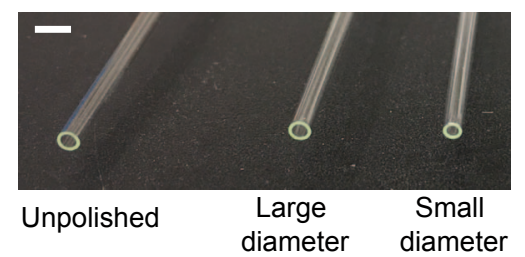

C

\section{Neuron plating scheme}

for immunoblotting

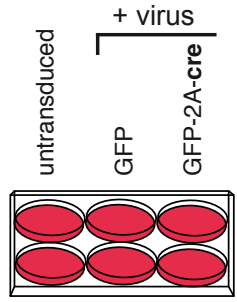

6-well plate for live-cell imaging

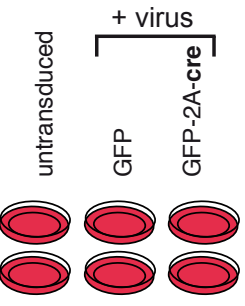

glass-bottom dishes for genotyping

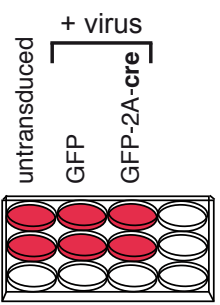

12-well plate for conditioned medium
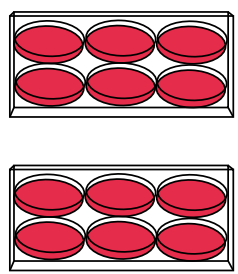

2x 6-well plates 
Bodakuntla et al., Figure 4
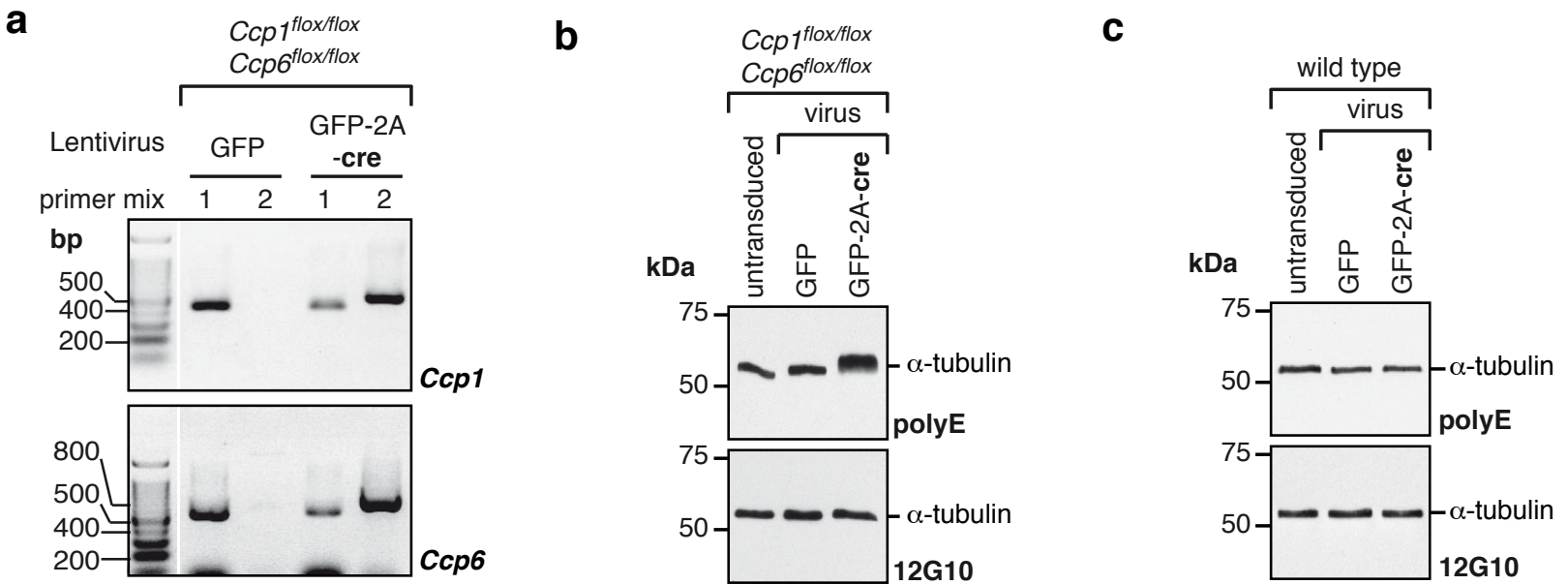